\section{Blue Grama Response to Nitrogen and Clipping Under Two Soil Moisture Levels ${ }^{1}$}

\author{
JERRY L. REED AND DON D. DWYER \\ Research Assistant and Professor of Range Management, \\ New Mexico State University, Las Cruces.
}

\section{Highlight}

Effects of $\mathbf{N}$-fertilization and clipping on production and water use of blue grama were evaluated under two soil moisture levels, field capacity and $1 / 5$ available water. Nitrogen increased shoot production $77 \%$ on unclipped plants. Clipping decreased shoot production $287 \%$ below the control averaged across $\mathbf{N}$ levels. Soil moisture levels produced no differences in yields. Root weights were decreased an average of $253 \%$ below the control by clipping. No differences were observed in total water used between fertilized and unfertilized plants but clipping reduced water used by $95 \%$. Unclipped plants fertilized with 80 \# N/acre used more water than unfertilized unclipped plants. The amount of water required to produce a unit of a shoot was reduced $37 \%$ when fertilized. Clipping lowered this water requirement an average of $98 \%$. Nitrogen greatly increased seed stalk numbers and the increase in shoot production due to fertilization came primarily from increased numbers of seed stalks.

Demands on agricultural land for increased production and nonagricultural purposes have necessitated research into methods of improving production on rangelands. The use of fertilizers offers a possibility for increasing rangeland productivity. Blue grama (Bouteloua gracilis [H.B.K.] Lag.) is dominant or co-dominant throughout much of the Great Plains and

\footnotetext{
${ }^{1}$ Journal article 344, Agricultural Experiment Station, New Mexico State University, Las Cruces. Received January 8, 1970; accepted for publication April 8, 1970.
}

at elevations of 4000 to 6000 feet in the West.

This study was a greenhouse evaluation of blue grama response to nitrogen fertilization under clipping and two soil moisture levels. Investigations were also made during a recovery period to determine possible carry-over effects of the treatments.

Nitrogen fertilization has increased yields on native ranges (Gay and Dwyer, 1965; Smika et al., 1963) and particularly blue grama ranges (Klipple and Retzer, 1959; Lehman et al., 1968; Rogler and
Lorenz, 1957). Reproductive capabilities may be enhanced by nitrogen fertilization as shown by increased seed production (Kneebone, 1957) and increased seed stalk numbers. Desirable carry-ovcr effects from nitrogen for as long as three to six years following application have been reported (Kay et al., 1957).

Blue grama responds quickly to both favorable and unfavorable stimuli. Yields may be seriously damaged by frequent clipping (Branson, 1956), although judicious harvesting may stimulate yields of blue grama and prove valuable in the planning of sound management systems (Jameson, 1963). Morphologically, blue grama is resistant to a relatively high level of defoliation because of the inaccessibility of its meristematic growing points (Branson, 1953).

Several studies have shown an increase in water requirement when soil moisture content approaches either extreme (Bennett and Doss, 1963; Briggs and Shantz, 1913). Regardless of the environment, water requirement was reduced when watering was postponed until high soil moisture tensions were reached (Letey and Blank, 1961). Shantz (1927) reported that $312 \pm 12$ grams of water were required to produce one gram of blue grama under greenhouse conditions. Clipping 
Table 1. Blue grama shoot and root weights (g) under nitrogen fertilization (lb./acre) and clipping.

\begin{tabular}{|c|c|c|c|c|}
\hline \multirow{2}{*}{$\begin{array}{l}\text { Clipping } \\
\text { treatments }\end{array}$} & \multicolumn{3}{|c|}{ Nitrogen } & \multirow[b]{2}{*}{ Mean } \\
\hline & 0 & 40 & 80 & \\
\hline \multicolumn{5}{|l|}{ Shoot weights } \\
\hline Clipped $^{2}$ & $2.89 \mathrm{a}^{1}$ & $3.14 \mathrm{a}$ & $3.17 \mathrm{a}$ & $3.07 \mathrm{a}$ \\
\hline Unclipped & $7.63 \mathrm{~b}$ & $12.55 \mathrm{c}$ & $15.46 \mathrm{c}$ & $11.88 \mathrm{~b}$ \\
\hline Mean & $5.26 \mathrm{a}$ & $7.85 \mathrm{ab}$ & $9.32 \mathrm{~b}$ & 7.48 \\
\hline \multicolumn{5}{|l|}{ Root weights } \\
\hline Clipped $^{2}$ & $3.94 \mathrm{a}$ & $3.92 \mathrm{a}$ & $3.59 \mathrm{a}$ & $3.82 \mathrm{a}$ \\
\hline Unclipped & $9.50 \mathrm{~b}$ & $14.22 \mathrm{~b}$ & $16.79 \mathrm{~b}$ & $13.50 \mathrm{~b}$ \\
\hline Mean & $6.72 \mathrm{a}$ & $9.07 \mathrm{a}$ & $10.19 \mathrm{a}$ & 8.66 \\
\hline
\end{tabular}

${ }_{1}$ Means with the same small letter are not significantly different within clipping level $(\mathbf{P}<.05)$.

2 All differences between clipped and unclipped are significantly different for all fertilizer levels $(\mathbf{P}<.05)$.

increased water requirement and made moisture stress effects more severe (Briggs and Shantz, 1913). Water requirement of range grasses was decreased by the addition of nitrogen (Lehman et al., 1968; Viets, 1962).

\section{Methods and Procedures}

Following a proccdure similar to that used by Keller (1954), twogallon ceramic pots seven inches in diameter and ten inches deep were filled with equal amounts of a thoroughly mixed, air-dry sandy soil. A three-inch by three-inch core of blue grama sod obtained at the Ft. Stanton Cooperative Range Research Station, Ft. Stanton, New Mexico, was inserted into the soil of each pot and allowed to become established at a field capacity water level.

Treatments were applied after a two month establishment period on forty-eight pots selected for their uniformity of stand of blue grama. These treatments were applied in a $3 \times 2 \times 2$ arrangement of three nitrogen levels $(0,40$, and $80 \mathrm{lb}$. N/ acre equivalents), two soil moisture levels (field capacity and one-fifth available water), and two clippings levels (no-clip and clipped to a $1 \frac{1 / 2}{2}$ inch stubble height every ten days), with four replications in a randomized block design. One-fifth available water was determined as $20 \%$ of the difference in weight of a given unit of soil at field capacity and at permanent wilting point measured in grams of water. Ammonium sulfate $(21 \% \mathrm{~N})$ was used as the source of nitrogen. Water levels were held constant for the entire 96 day sampling period, after which all treatments were clipped. All pots were then raised to field capacity and allowed to recover for 48 days, after which they were all clipped to determine final production.

Production, water usage, and water requirement were measured

Table 2. Blue grama water use (g) and water requirement (g) under conditions of nitrogen fertilization (lb. N/acre) and clipping.

\begin{tabular}{lccrc}
\hline \hline \multirow{2}{*}{$\begin{array}{c}\text { Clipping } \\
\text { treatment }\end{array}$} & \multicolumn{3}{c}{ Nitrogen level } & \multirow{2}{*}{ Mean } \\
\cline { 2 - 4 } Total water used & & 40 & 80 & \\
$\quad$ Clipped & $6,317 \mathrm{a}^{1}$ & $5,936 \mathrm{a}$ & $6,153 \mathrm{a}$ & $6,134 \mathrm{a}$ \\
Unclipped & $10,078 \mathrm{~b}$ & $12,058 \mathrm{bc}$ & $13,647 \mathrm{c}$ & $11,955 \mathrm{~b}$ \\
Mean & $8,089 \mathrm{a}$ & $8,729 \mathrm{a}$ & $9,532 \mathrm{a}$ & 8,804 \\
Water requirement & ${ }^{2}$ & & & \\
Clipped & $2,222 \mathrm{a}$ & $1,923 \mathrm{a}$ & $1,961 \mathrm{a}$ & $2,041 \mathrm{a}$ \\
Unclipped & $1,333 \mathrm{~b}$ & $962 \mathrm{c}$ & $877 \mathrm{~d}$ & $1,031 \mathrm{~b}$ \\
Mean & $1,667 \mathrm{a}$ & $1,282 \mathrm{ab}$ & $1,219 \mathrm{~b}$ & 1,370
\end{tabular}
Means with same letter are not significantly different in clipping treatments and nitrogen levels $(\mathbf{P}<.05)$.

${ }^{2}$ Grams of water required per gram of shoot produced. 
Table 3. Blue grama shoot yields (g) following 48 day recovery under prior conditions of nitrogen fertilization (lb./acre) and soil moisture levels.

\begin{tabular}{lcccc}
\hline \hline \multirow{2}{*}{\multicolumn{1}{c}{ Moisture }} & \multicolumn{3}{c}{ Nitrogen level } & \\
\cline { 2 - 4 } & 0 & 40 & 80 & Mean \\
\hline Field capacity & $4.31 \mathrm{a}^{1}$ & $5.71 \mathrm{ab}$ & $6.19 \mathrm{~b}$ & $5.40 \mathrm{a}$ \\
$1 / 5$ available water ${ }^{2}$ & $4.81 \mathrm{ab}$ & $5.05 \mathrm{ab}$ & $4.75 \mathrm{ab}$ & $4.87 \mathrm{a}$ \\
Average & $4.56 \mathrm{a}$ & $5.38 \mathrm{~b}$ & $5.47 \mathrm{~b}$ & 5.14 \\
\hline
\end{tabular}

Means with the same letter are not significantly different within moisture level $(\mathbf{P}<.05)$.

2 Maintained at field capacity during recovery period.

of additional grass produced over the control per $\mathrm{g}$ of $\mathrm{N}$ applied, was $44.3 \mathrm{~g}$ at the $40 \mathrm{lb}$. $\mathrm{N} /$ acre rate and $35.3 \mathrm{~g}$ at the $80 \mathrm{lb}$. rate.

Clipping reduced above ground yields by $287 \%$ compared to the unclipped treatment averaged across $\mathrm{N}$ levels (Table 1). Increased production due to fertilization was not apparent when clipping treatments were applied. It appears that the addition of nitrogen to blue grama which is maintained at a clipping height below two inches will not give increased yields. This is supported by other work (Dwyer, 1969).

There was no difference in yields between the field capacity and onefifth available water levels, an indication of the ability of blue grama to produce forage under conditions of limited moisture supply.

\section{Root Production}

Neither fertilization rates when averaged across clipping levels nor soil moisture levels produced differences in root weights (Table 1). Clipping reduced root weights $253 \%$ below those of the unclipped plants, almost the same reduction shown by the shoot production data. Roots, like the shoots, did not respond favorably to additions of $\mathrm{N}$ under relatively severe clipping.

\section{Root : Shoot Ratios}

Root weights exceeded shoot weights an average of $16 \%$ for each treatment, but no differences wcre shown in root : shoot ratios for any treatment. The response of roots and shoots to the treatments was about equal.

\section{Water Usage}

There were no significant differences in total water used between fertilizer rates on clipped plants, but there were differences on unclipped plants (Table 2). Clipping reduced the total water used by $95 \%$ compared to unclipped plants averaged across $\mathbf{N}$ levels.

\section{Water Requirement}

Fertilization rates and clipping levels both produced differences in the water requirement of blue grama (Table 2), but there was no difference between the field capacity and one-fifth available water levels.

Nitrogen applied at 40 and $80 \mathrm{lb}$. $\mathrm{N} /$ acre rates reduced the water requirements below the control when averaged across clipping treatments by $30 \%$ and $37 \%$, respectively. It appears that blue grama is more efficient in water use under $\mathbf{N}$ fertilization. The absence of response from moisture levels indicates that this increase in water use efficiency due to fertilization may exist within a wide range of available moisture.

Clipping also decreased water re- quirement to about half of the water required for unclipped grass.

\section{Recovery Study}

Shoot production.-Nitrogen fertilization continued to influence shoot production of blue grama during the 48 day recovery period. Results at the end of this period showed that the 40 and $80 \mathrm{lb} . \mathrm{N} /$ acre rates increased yields 18 and $20 \%$, respectively, over the control when averaged across moisture levels, however, fertilizer had no influence at the one-fifth available water level (Table 3). This increase amounted to a $\mathrm{N}$ efficiency of $7.4 \mathrm{~g}$ of grass produced over the control per $\mathrm{g}$ of $\mathrm{N}$ added at the $40 \mathrm{lb} . \mathrm{N} /$ acre rate, and $4.1 \mathrm{gm}$ of grass $/ \mathrm{g}$ of $\mathrm{N}$ at the $80 \mathrm{lb}$. rate.

Soil moisture levels alone had no influence on yields when carry-over effects were tested.

Blue grama apparently recovered quickly from defoliation since following the 48 day recovery period, there was no carry-over effect from clipping on yields (Table 4).

Water usage.-The carry-over effects of treatments showed that water used at field capacity under $80 \mathrm{lb} . \mathrm{N} /$ acre is greater than that used at 0 and $40 \mathrm{lb}$. of $\mathrm{N}$. Also, water used was less for $80 \mathrm{lb}$. N than for 0 under one-fifth available water (Table 5).

Those grasses previously maintained at one-fifth available moisture used $17 \%$ less water during recovery than those grasses previously maintained at field capacity when averaged across fertilizer levels.

The carry-over effects of clipping continued to reduce water use.

Table 4. Blue grama shoot yields (g) following 48 day recovery under prior conditions of nitrogen fertilization (lb./acre) and clipping.

\begin{tabular}{lcccc}
\hline \hline \multirow{2}{*}{ Treatment } & \multicolumn{3}{c}{ Nitrogen level } & \\
\cline { 2 - 4 } & 0 & 40 & 80 & Mean \\
\hline Previously clipped & $4.99 \mathrm{a}^{1}$ & $5.35 \mathrm{a}$ & $4.78 \mathrm{a}$ & $5.04 \mathrm{a}$ \\
Unclipped & $4.14 \mathrm{a}$ & $5.41 \mathrm{ab}$ & $6.16 \mathrm{~b}$ & $5.24 \mathrm{a}$ \\
Average & $4.56 \mathrm{a}$ & $5.38 \mathrm{ab}$ & $5.47 \mathrm{~b}$ & 5.14 \\
\hline
\end{tabular}

${ }^{1}$ Means with the same letter are not significantly different within clipping treatment $(\mathrm{P}<.05)$. 
Table 5. Total water used (g) and water requirement (g) for blue grama during a 48 day recovery period under prior conditions of nitrogen fertilization (lb./acre) and soil moisture levels.

\begin{tabular}{|c|c|c|c|c|}
\hline \multirow{2}{*}{$\begin{array}{c}\text { Water } \\
\text { measurement }\end{array}$} & \multicolumn{3}{|c|}{ Nitrogen level } & \multirow[b]{2}{*}{ Mean } \\
\hline & 0 & 40 & 80 & \\
\hline \multicolumn{5}{|l|}{ Total water used ${ }^{1}$} \\
\hline Field capacity & $4180 \mathrm{Ba}$ & $4328 \mathrm{Ba}$ & $4661 \mathrm{Bb}$ & $4390 \mathrm{Ba}$ \\
\hline $1 / 5$ available water ${ }^{2}$ & $3861 \mathrm{Ab}$ & $3878 \mathrm{Ab}$ & $3550 \mathrm{Aa}$ & $3763 \mathrm{Ab}$ \\
\hline Average & $4020 \mathrm{Ba}$ & $4103 \mathrm{Ba}$ & $4106 \mathrm{Aa}$ & 4076 \\
\hline \multicolumn{5}{|l|}{ Water requirement ${ }^{3}$} \\
\hline Field capacity & $962 \mathrm{Bb}$ & 746Aa & $741 \mathrm{Aa}$ & $806 \mathrm{Ba}$ \\
\hline $1 / 5$ available water ${ }^{2}$ & $800 \mathrm{Aa}$ & $769 \mathrm{Aa}$ & $763 \mathrm{Aa}$ & $775 \mathrm{Aa}$ \\
\hline Average & $881 \mathrm{Bb}$ & $757 \mathrm{Aa}$ & $752 \mathrm{Aa}$ & 791 \\
\hline
\end{tabular}

1Means with same small letter are not significantly different for soil moisture. Those with capital letter are not significantly different for $\mathrm{N}$ level $(\mathbf{P}<.05)$.

2 Maintained at field capacity during recovery period.

${ }^{3}$ Grams of water required per $g$ shoot produced.

Table 6. Total water used (g) during 48 day recovery period under prior conditions of nitrogen fertilization (lb./acre) and clipping.

\begin{tabular}{llccc}
\hline \multirow{2}{*}{$\begin{array}{c}\text { Clipping } \\
\text { treatment }\end{array}$} & \multicolumn{3}{c}{ Nitrogen level } \\
\cline { 2 - 4 }
\end{tabular}

Means with the same letter are not significantly different within clipping level $(\mathbf{P}<.05)$.

Those samples previously clipped used $15 \%$ less water than those samples not clipped (Table 6).

Water requirement.-Fertilization and clipping both showed differences in water requirement when carry-over effects of the treatments were measured (Tables 5 and 6).

Nitrogen at both the 40 and 80 lb. $N$ /acre rates decreased the water required to produce a gram of shoot below those of the control (Table 6).

Carry-over clipping effects also decreased the water requirement of blue grama.

\section{Source of Increased Production from Fertilized Plants}

Significant increases in shoot production from fertilized plants have been shown in this and numerous other studies. This portion of the experiment was an attempt to determine from which plant parts this increased production comes.
Blade length.-Based on fertilization and water level treatments without clipping, blade length differences appeared only as a result of water level influence. Leaf lengths under the field capacity water level were $16 \%$ greater than those under the one-fifth available water level (Table 7).

No treatments were found to have any measurable effect on seed stalk height.

Leaves per seed stalk.-Fertilization produced no differences in number of leaves per seed stalk, but the field capacity water level averaged an $8 \%$ increase in number over the one-fifth available moisture group.

Seed stalk numbers.-Seed stalk numbers were increased considerably over the control as a result of fertilization. The 40 and $80 \mathrm{lb}$. N/ acre rates produced $142 \%$ and $263 \%$ more seed stalks, respectively, than the control.

Soil moisture levels produced no differences in seed stalk numbers.

Spike numbers.-The number of inflorescence spikes per plant was not affected by water levels, how-

Table 7. Blue grama leaf blade lengths $(\mathrm{mm})$, leaves per seed stalk, seed stalk numbers and spike numbers on unclipped plants under nitrogen fertilization (lb./acre) and soil moisture levels.

\begin{tabular}{|c|c|c|c|c|}
\hline \multirow{2}{*}{$\begin{array}{l}\text { Measurement } \\
\text { and moisture } \\
\text { conditions }\end{array}$} & \multicolumn{3}{|c|}{ Nitrogen level } & \multirow[b]{2}{*}{ Mean } \\
\hline & 0 & 40 & 80 & \\
\hline \multicolumn{5}{|l|}{ Leaf blade length } \\
\hline Field capacity & $177.5 \mathrm{Aa}^{1}$ & $184.6 \mathrm{Aa}$ & $190.6 \mathrm{Aa}$ & $184.2 \mathrm{Ba}$ \\
\hline $1 / 5$ available water & $143.7 \mathrm{Aa}$ & $163.8 \mathrm{Aa}$ & $169.0 \mathrm{Aa}$ & $158.8 \mathrm{Aa}$ \\
\hline Average & $160.6 \mathrm{~A}$ & $174.2 \mathrm{~A}$ & $\mathrm{I} 79.8 \mathrm{~A}$ & 171.5 \\
\hline \multicolumn{5}{|l|}{ No. leaves/seed stalk } \\
\hline Field capacity & $3.45 \mathrm{Ba}$ & $3.50 \mathrm{Ba}$ & $3.45 \mathrm{Ba}$ & $3.47 \mathrm{Ba}$ \\
\hline $1 / 5$ available water & $3.15 \mathrm{Aa}$ & 3.38Aa & $3.15 \mathrm{Aa}$ & $3.22 \mathrm{Ab}$ \\
\hline Average & $3.30 \mathrm{Ba}$ & $3.44 \mathrm{Aa}$ & $3.30 \mathrm{Aa}$ & 3.34 \\
\hline \multicolumn{5}{|l|}{ No. seed stalks/pot } \\
\hline Field capacity & $22.00 \mathrm{Aa}$ & $55.25 \mathrm{Ab}$ & $85.50 \mathrm{Ac}$ & $54.25 \mathrm{Ab}$ \\
\hline $1 / 5$ available water & $22.75 \mathrm{Aa}$ & $53.00 \mathrm{Ab}$ & $77.00 \mathrm{Ac}$ & $50.92 \mathrm{Ab}$ \\
\hline Average & $22.38 \mathrm{Aa}$ & $54.13 \mathrm{Ab}$ & $81.25 \mathrm{Ac}$ & 52.58 \\
\hline \multicolumn{5}{|l|}{ Spike numbers } \\
\hline Field capacity & $25.00 \mathrm{Aa}$ & $68.75 \mathrm{Ab}$ & $93.75 \mathrm{Ac}$ & $62.50 \mathrm{Ab}$ \\
\hline $1 / 5$ available water & $24.50 \mathrm{Aa}$ & $70.75 \mathrm{Ab}$ & $93.00 \mathrm{Ac}$ & $62.75 \mathrm{Ab}$ \\
\hline Average & $24.75 \mathrm{Aa}$ & $69.70 \mathrm{Ab}$ & 93.37Ac & 62.63 \\
\hline
\end{tabular}

${ }_{1}$ Means with the same small letter are not significantly different for that moisture level. Those with capital letters are not significantly different for that $\mathrm{N}$ level $(\mathbf{P}<.05)$. 
ever, the 40 and $80 \mathrm{lb} . \mathrm{N} /$ acre fertilization rates produced $181 \%$ and $277 \%$ more spikes, respectively, than the non-fertilized treatment.

These data imply that in addition to increased forage production, seed stalk and spike numbers due to $\mathrm{N}$-fertilization, the reproductive capabilities of blue grama may be simultaneously improved. The increase in production due to $\mathrm{N}$ fertilization comes primarily from increased numbers of reproductive parts, namely flowering culms, or seed stalks and spikes. This, of course, implies more total leaf blades and sheaths since each seed stalk has an average of 3.34 leaves.

Overall the data from this study on blue grama infer that: 1) shoot and root production are both increased about the same order of magnitude with addition of $\mathrm{N}, 2$ ) no increase in production of shoots and roots is found with $\mathrm{N}$ addition when blue grama is clipped to $1 \frac{1 / 2}{2}$ inch stubble height every 10 days, 3) clipping reduced the total water used nearly $100 \%$, 4) clipping increased the water required per unit of shoot produced about 100\% and 5) $\mathrm{N}$ fertilization reduced this requirement $37 \%$.

\section{Literature Cited}

Bennett, O. L., And B. D. Doss. 1963. Effects of soil moisture regime on yield and evapotranspiration from cool-season perennial forage species. Agron. J. 55:275-278.

Blydenstern, John. 1966. Root systems of four desert grassland species on grazed and protected sites. J. Range Manage. 19:93-95.

Branson, F. A. 1956. Quantitative effects of clipping treatments on five range grasses. J. Range Manage. 9: $86-88$.

Branson, F. A. 1953. Two ncw factors affecting resistance of grasses to grazing. J. Range Manage. 6:165171.

Briggs, L. J., and H. L. Shantz. 1913. The water requirement of plants, part II. U.S. Dep. Agr. Bur. Plant Ind. Bull. 285.

Crider, Franklin J. 1955. Rootgrowth stoppage resulting from defoliation of grass. U.S. Dep. Agr. Tech. Bull. 1102. 23 p.

DWyer, Don D. 1969. Greenhouse production of blue grama as influcnced by clipping and nitrogen fertilization. N. Mex. Agr. Exp. Sta. Bull. 549. 8 p.

Gay, C. W., and D. D. Dwyer. 1965. Effect of one year's nitrogen fertilization on native vegetation under clipping and burning. J. Range Manage. 18:273-277.

Jameson, Donald A. 1963. Responses of individual plants to harvesting. Bot. Rev. 29:532-594.

Kay, B. L., J. E. Street, and C. W. Rimbey. 1957. Nitrogen carry-over on range. Calif. Agr. 11(10):5 and 10.

Keller, W. 1954. Water requirement of selected genotypes of or- chardgrass, Dactylis glomerata L. Agron. Jour. 45:622-625.

Klipple, G. E., and John L. Retzer. 1959. Response of native vegetation of the Central Great Plains to applications of corral manure and commercial fertilizer. J. Range Manage. 12:239-243.

Kneebone, William R. 1957. Blue grama seed production studies. J. Range Manage. 10:17-21.

Lehman, O. R., J. J. Bond, and H. V. EcK. 1968. Forage potential of irrigated blue grama with nitrogen fertilization. J. Range Manage. 21: 71-73.

Letey, J., and G. B. Blank. 1961. Influence of environment on the vegetative growth of plants watered at various soil moisture suctions. Agron. J. 53:151-153.

Rogler, George A., ANd Russell J. LORENZ. 1957. Nitrogen fertilization of Northern Great Plains rangelands. J. Range Manage. 10:156-160.

Shantz, H. L. 1927. The water requirement of plants at Akron, Colorado. J. Agr. Res. 34:1093-1190.

Smika, D. E., H. J. HaAs, and G. A. Rogler. 1963. Native grass and crested wheatgrass production as influenced by fertilizer placement and weed control. J. Range Manage. 16: 5-8.

Steele, R. G. D., and H. J. Torrie. 1960. Principles and procedures of statistics. McGraw-IIIll Book Co., Inc. New York. 481 p.

Viets, Frank G., JR. 1962. Fertilizers and the efficient use of water. Adv. in Agron. 14:223-264.

\section{Reprints}

Individual reprints of articles appearing in the Journal of Range Management may be obtained from the author(s). Send your request for reprints to the author at his address shown in the article head or accompanying footnote.

Individual reprints are not available from the Editor or from the Society office. 